DOI: https://doi.org/10.34069/AI/2021.48.12.11

How to Cite:

Mizin, K., Slavova, L., Lyashuk, A., \& Hromovenko, V. (2021). The emotion concept of SHAME as one of the markers of social infantilism: Cross-cultural analysis based on language corpora data. Amazonia Investiga, 10(48), 97-106. https://doi.org/10.34069/AI/2021.48.12.11

\title{
The emotion concept of SHAME as one of the markers of social infantilism: Cross-cultural analysis based on language corpora data
}

\section{Емоційне поняття СОРОМ як один із маркерів соціального інфантилізму: крос-культурний аналіз на основі даних мовних корпусів}

Received: October 10, 2021

\section{Abstract}

The article presents a cross-cultural analysis of those ethnocultural features of the emotion concept of SHAME in Ukrainian, Anglo-Saxon and German linguo-cultures, which directly correlate with some national characteristics of the representatives of these linguo-cultures. It deals with the role of shame in the generation of such a social phenomenon as infantilism, since the significant spread of this phenomenon in a particular linguo-society is the basis for determining infantilism as one of the features of the national character. A comparative study of the representative corpora data of Ukrainian, English and German has revealed that Ukrainians, although a European linguo-society, belong not to guilt culture, as the Anglo-Saxons and Germans, but to shame culture, because this emotion arises in them mostly in in-groups, transforming into shame, humiliation, pangs of conscience, but not guilt. This feature of Ukrainians' psychological type brings them closer to Eastern cultures, correlating to the greatest extent with such a criterion of cultures distinctions as collectivism-individualism. The low rate of individualism in the Ukrainian
Accepted: December 17, 2021

Written by:

Kostiantyn Mizin ${ }^{36}$

https://orcid.org/0000-0002-5216-6032

Liudmyla Slavova ${ }^{37}$

https://orcid.org/0000-0001-8035-1801

Anna Lyashuk ${ }^{38}$

https://orcid.org/0000-0003-3186-5755

Viktoriia Hromovenko ${ }^{39}$

https://orcid.org/0000-0001-6706-3231

\footnotetext{
${ }^{36}$ DrSc. (Philology), Full Professor of Foreign Philology, Translation and Teaching Methodology Department of Hryhorii Skovoroda University in Pereiaslav, Ukraine.

${ }^{37}$ DrSc. (Philology), Professor of the Theory and Practice of Translation from English Department, Taras Shevchenko National University of Kyiv, Ukraine.

${ }^{38} \mathrm{PhD}$ (Philology), Associate Professor, a doctorate student of the Theory and Practice of Translation from English Department, Taras Shevchenko National University of Kyiv, Ukraine.

${ }^{39} \mathrm{PhD}$ (Philology), Associate Professor of the Department of Foreign Languages for Professional Communication, International Humanitarian University, Ukraine.
} 
linguo-society has led to the fact that Ukrainians tend to be less responsible for their actions than Anglo-Saxons or Germans, often shifting their responsibility to external factors. The unwillingness of a large number of individuals to take responsibility indicates a certain immaturity of the society as a whole. This gives grounds to claim that the concept COPOM is one of the markers of social infantilism of the Ukrainian people.

Key words: emotion concept, shame, infantilism, language corpus, linguo-culture.

\section{Introduction}

In cross-cultural studies, in particular linguistics, the tendency to identify common and divergent features in the structure, functioning and development of social and psychological phenomena in different linguocultures dominates. One of such phenomena is the concept of "national character" (Inkeles, 1997), which has long been criticized for some scientific bias (Farber, 1950, p. 307; McCrae \& Terracciano, 2006, p. 156). However, methodological problems have not become an obstacle to the spread of this concept in a number of culturally oriented disciplines, including linguistic ones. This is especially true of ethnolinguistics, psycholinguistics, and sociolinguistics, as well as post-Soviet versions of cultural linguistics - linguoculturology and linguoconceptology - whose followers operate with the concept of "national character" without much reservation as to its objectivity.

Cross-cultural studies of national characters are extremely relevant today, because they directly correlate with the acute problem of today globalization. The latter encourages a number of issues of intercultural understanding, especially intercultural contacts and barriers. These barriers do not disappear, as globalization, in its turn, actualizes anti-globalization processes, which show, for example, some ethnocentric tendencies within the European linguo-cultural space.

The objectivity of the identification of national traits requires the disclosure of the features of the emotional world of the respective linguo-ethnic group, as the study of emotions (emotional states, feelings) can provide scientifically reliable data on the specifics of world perception and understanding of both individuals and ethnic groups as a whole. Such conclusions were колективізм - індивідуалізм. Низький показник індивідуалізму в українському лінгвосоціумі зумовив те, що українці схильні до меншої відповідальності за свої вчинки, ніж англосаксонці або німці, часто перекладючи свою відповідальність на зовнішні чинники. Неготовність значної частини індивідів брати на себе відповідальність свідчить про певну незрілість колективу в цілому. Це дає підстави стверджувати, що поняття СОРОМ є одним із маркерів соціального інфантилізму українського народу.

Ключові слова: емоційне поняття, сором, інфантильність, мовний корпус, лінгвокультура.

reached by A. Wierzbicka and Z. Kövecses in their fundamental works (Kövecses, 1986, 1990; Wierzbicka, 1999), due to which they initiated a detailed study of emotion concepts in numerous cognitive and culturally oriented linguistic studies in the late twentieth century. In fact, they introduced the term emotion concepts into scientific circulation. At present, the fact that they are clearly expressed cultural concepts does not provoke much discussion among scholars (Kitayama \& Markus, 1997; Kövecses, 1990; Schwarz-Friesel, 2008; Wierzbicka, 1999). This is the reason why the emotion concept of SHAME, which is the object of the study in our paper, should be considered as a cultural concept, i.e. the one that can reveal the specifics of world perception and world understanding of a particular linguo-culture.

\section{Theoretical Framework}

Emotions correlate with human cognition and language (Schwarz-Friesel, 2008, p. 277). Therefore, the methodological basis for identifying the cultural specificity of emotion concepts is the conclusion of psychologists and linguists that in the process of social interaction of individuals even basic (universal) emotions receive socio- and ethnocultural semantic nuances that influence their expression and perception in a particular linguo-society (Friedlmeier, Corapci, \& Cole, 2011; Lewandowska-Tomaszczyk, 2017; Mizin \& Petrov, 2021).

In addition, within the mentioned interaction there is a symbiotic synergy of basic emotions, which gives rise to numerous combinations of the latter. Purely "human" - social (derivative, complex) - emotions are formed this way 


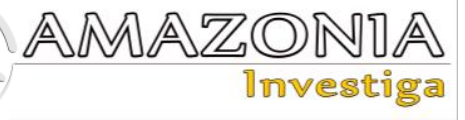

(Levenson, 2011), a bigger part of which demonstrates a clear cultural marking. Social emotions are the result of the dynamics of the emotional world of a person, being an amalgam of two or more emotions. Their "blurred" nature is the reason that, despite the involvement of modern techniques and technical capabilities, the number of social emotions is still uncertain (Cowen \& Keltner 2017; Du, Tao, \& Martinez, 2014). It is noteworthy that there is no common point of view on the criteria for distinguishing between basic and social emotions among the scholars. Therefore, these emotions in some works are defined as basic, and in others - as social. Shame is one of such emotions, which is under consideration in our paper.

Psychologists generally hold the view that shame is a complex, i.e., social emotion, although it is considered as a basic one in some studies (Izard, 1992). Obviously, this is due to the fact that shame, although being not considered as an innate (basic) emotion, reveals at least some of the characteristics that are inherent to basic emotions (Tracy \& Matsumoto, 2008, p. 11655). First of all, it concerns the distinct manifestation (expression) of this emotion by the human physiology - blushing of the face, aversion of the eyes, lowering of the head, and so on. However, shame is characterized by signs of the social emotion, as it can occur only in the presence of another person / other people who evaluates / who evaluate the morality of the individual's actions. At the same time, the issue of selfesteem is no less important, because the lower the self-esteem, the more intensely the individual experiences shame.

Shame is considered to be an important moral and regulatory mechanism not only of a personal but also of public life, so the cultural concept of SHAME is relevant to any linguo-culture. As a regulator of social relations, it performs a moral and ethical function (Vdovychenko, 2015). If we take into account the fact that the norms of morality in different linguistic ethnic groups differ slightly, as they depend on the type of culture, it is reasonable to assume that the emotion concept of SHAME plays a significant role in shaping traits of the national character. Moreover, shame as a sociocultural phenomenon, may even be one of the criteria for the division of cultures (Benedict, 1989).

All issues related to cross-cultural differences are quite "sensitive" for any nation, especially national groups. The pressure of globalization makes them even more "sensitive". Therefore, even minor comments on the specifics of "our" or "their" linguo-cultures now require objective scrutiny, as they may contain a certain amount of ethnocentric "distortion". It is because of this "distortion" that both the objectivity of national (or ethnic) stereotypes and their relevance are questionable, because they often do not correspond to reality due to the significant dynamics of socio- and ethnocultural changes.

Such typical features of Ukrainians as love of freedom (desire for freedom), emotionality ("cordocentrism"), irrationality, religiosity, individualism, introversion (projecting one's own activity on oneself), stubbornness, diligence and hospitality have been distinguished by Ukrainophile researchers (Kulchytskyi, 1949; Yaniv, 2006) for a long time. They may have been relevant to the Ukrainian-speaking community in the previous or the last but one century, but not today, when the impact of globalization, democratization and liberalization on the Ukrainian society is becoming more and more noticeable. At least, some of these features are certainly not true any more, but continue to exist at the level of auto- and heterostereotypes. Thus, recent sociological research has found that the rate of individualism among Germans reaches 67, among Poles - 60, among Russians 39, and among Ukrainians - 25 (Hofstede Insights, 2019). Although ethnographers of the past centuries were convinced that Ukrainians are more individualistic than Russians (Kostomarov, 1991, p. 61). Apparently, there were some objective reasons for that at that time. The same concerns such a feature as being hard working. In our opinion, it is also irrelevant for modern Ukrainians, because there can be no bumpy roads, untidy houses, neglected estates, abandoned public areas and a permanently depressed economy in a hard-working nation. It is impossible to talk about religiosity without irony, because the Orthodox religion is mostly a "fashion" for weddings, baptisms, funerals, etc. for the current generation, so the religiosity of many Ukrainians is more pretentious than sincere.

There are some grounds for assuming that the very concept of "national character" is methodologically somewhat incorrect in relation to the Ukrainian society. In particular, after 30 years of Ukrainian independence the third President of Ukraine V. Yushchenko acknowledged that Ukrainians still remain a "quasi-nation" (Yushchenko, 2021). This national inferiority was caused by historical, geopolitical, socio-cultural and ethnocultural factors. The role of the psychological type of the people is important here, as the immaturity of 
Ukrainians as a nation is obviously connected with immaturity (infantilism) as a feature of their character. The problem of social infantilism has become even more relevant in the Ukrainian society after the 2019 presidential election, as this feature is associated with V.Zelensky's voters according to a number of public figures (Hopko, 2019; Hundorova, 2019; Kozlovskyi, 2021).

Infantilism is closely correlated with the emotional world of the individual and society as a whole, because it influences the social expression of emotions by the individual (Rotenberg, 2009, p. 163). In their turn, social emotions themselves, as cultural concepts, are directly involved in the formation of social infantilism. And because the infantile person has problems regulating their behavior in a certain group of people due to increased suggestibility, emotional imbalance, low level of development of a sense of duty and responsibility, it is primarily about regulatory emotions, including shame.

In view of the abovementioned, the purpose of our study is to establish those ethnocultural features of the emotion concept of SHAME, which directly correlate with some national characteristics of the representatives of Ukrainian, Anglo-Saxon and German linguocultures. On the one hand, shame, showing socioand ethnocultural significance, can more or less determine the basic characteristics of the concept of the "national character", and on the other hand, these characteristics themselves influence the formation of shame as a social emotion. We are speaking primarily about the role of shame in the generation of such a social phenomenon as infantilism, as the significant spread of the latter in a particular linguo-culture, in particular in Ukrainian, suggests that infantilism may become a national trait (Strazhnyi, 2017, p. 415). To prove the scientific objectivity of this assumption, the proposed study involves corpora-based data.

\section{Methodology}

In Western European science, the objectivity of research methodology is paid much attention to. This also applies to those works in which anthropologists, sociologists, psychologists or linguists touch on "subtle matter" - the characteristic features of the mentality of a particular linguistic ethnic group. Instead, in the post-Soviet scientific space, the truth of statements about character traits of the nation is often based on the conclusions of philosophers, culturologists, or even theologians. Although such statements must be based on empirical evidence and involve a scientifically sound methodology, because otherwise they cannot be considered objective enough. In addition, in the field of linguistics, the study of the specifics of the mentality of a particular linguo-culture is considered more scientifically correct if it is based on the material of different - related and unrelated - languages, as this allows avoiding erroneous, in particular linguo-narcissistic conclusions, which are often observed in monolingual studies (Mizin \& Korostenski, 2020, p. 114).

Taking into account the purpose of the proposed study, it is necessary to identify the ethnocultural specificity of the emotion concept of COPOM in the Ukrainian-speaking society, which could be one of the factors that contributed to the formation of Ukrainian infantilism. Data from the language corpora are used to establish the ethnocultural semantics of shame, because at the beginning of the third decade of the XXI century it can be reasonably argued that the methodology of corpus linguistics is quite objective in terms of studying cultural concepts (Mizin, Slavova, \& Khmara, 2021; Stefanowitsch, 2020). Language corpora in interlingual studies should be balanced (as far as possible) in terms of volume, structure and technical capabilities (set of tools). The English-language iWeb (iWeb, 2021) corpus, the German-language Digitales Wörterbuch der deutschen Sprache (DWDS, 2021) and the Ukrainian-language General Regional Annotated Corpus of the Ukrainian Language (GRAC-13 version) (GRAC, 2021) meet this requirement, because they are, firstly, representative, and secondly, are freely available, thirdly, have a similar volume and structure, and fourthly, the collocation strength indices used in these corpora (logDice and MI-index) are to some extent related.

The iWeb corpus contains 14 billion words (22 million web pages represented by different types of discourses: Internet discourse, publicistics, science, fiction, etc.). The volume of the DWDS corpus is currently more than 27 billion tokens. The basis for the automatic creation of word profiles is a newspaper corpus of about 3 billion tokens. These profiles provide data on the frequency of left and right collocates of query words (a general list and lists separately for each part of speech) and co-occurrences. The function of automatic creation of similar profiles is also available in iWeb and GRAC corpora. However, in methodological terms, the volume of the GRAC corpus is somewhat problematic, as its 


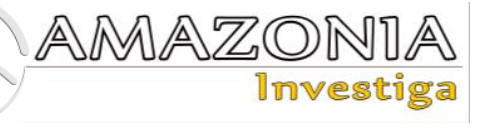

latest version - GRAC-13 - contains only 861 million tokens. However, today it is the largest corpus of the Ukrainian language.

It should be noted that the logDice and MI-index, although developed on the basis of different techniques, but serve one purpose - to establish a typical compatibility and "weed out" a random one, so these indices can be considered, at least for the purposes of this study, essentially relevant ones. There are more than eight dozen such statistical metrics for estimating word compatibility. They allow calculating the strength of the connection between the elements of phrases, based on the frequency of these phrases and their constituent words.

\section{Results and Discussion}

Studying Japanese linguistic culture, the American anthropologist R. Benedict (1989) came to the conclusion that the emotion of shame has a significant role for the Japanese in the process of regulating of social relations. This became the basis for determining the latter as one of the criteria on the basis of which the cultures of East and West are divided. According to this scholar, a "guilt culture" is characteristic for Europeans, and a "shame culture"- for the Japanese. The phenomenon of "guilt culture" is obviously associated with a high rate of individualism in the European cultural space (Hofstede Insights, 2019), because the individualistic nature is focused on assessing the responsibility for choosing a model of behavior in a relevant situation of social interaction. On the contrary, the "shame culture" of the Japanese is based on a sense of internal solidarity (corporatism) of groups, so the individual is ashamed of their actions to violate generally accepted norms and cause inconvenience to members of "their" group. This conclusion is consistent with the position of psychologists, who argue that members of European individualistic cultures are more prone to emotions that give them distance and independence. Here, the role of emotions is related to the individual's self-expression, personal aspirations and interests. But in collectivistic cultures, a person is more apt to the emotions that are responsible for the interaction and relationship between members of the group and contribute to its adaptation in this team (Breslav, 2004, p. 468).

This gives grounds to assert that the division of cultures by R. Benedict according to the emotional criterion coincides to some extent with the division of cultures into collectivistic and individualistic (see, e.g., Hofstede, 2006). The relevance of the emotion of guilt for members of individualistic linguo-societies is obviously related to Christianity, as confession and repentance have helped individuals develop a sense of responsibility for their sins. In such linguo-societies, a person does not look for the reasons for their sinful actions outside of their own "I", but, feeling guilty, takes responsibility.

The ability of the representatives of individualistic cultures not to shift responsibility for their actions onto someone else directly correlates with another criterion, according to which different linguo-societies are differentiated. This criterion is the locus of control. This concept was introduced by the social psychologist J. Rotter (1954) as an indicator of the localization of individuals' conation. Later on, this indicator came into use as one of the characteristics of a psychological type of a particular nation. Representatives of linguosocieties who are inclined to credit their success or failures to external factors have an external locus of control. And vice versa, if the results of activities are extrapolated to internal factors, namely conation, then we are talking about an internal locus of control. It is believed that utter individualists like Anglo-Saxons and Germans have an inherent internal locus of control.

This fact is also confirmed by the research results through the lens of the concept of cultural standards by A. Thomas (2018), which correlates with the abovementioned G. Hofstede's approach in terms of most criteria (sense of community / individualism, hierarchical orientation, regulation of interpersonal distance, orientation towards the result, tendency to preserve dignity, etc. Cultural standards are the ways of perceiving, thinking, judging and acting, which are perceived and considered by representatives of a certain linguo-society not only in the context of their behaviour but also concerning others as normal, typical, or even obligatory. These standards are adopted by an individual in the course of growing up and development and are reflexively manifested during social interaction. The followers of A. Thomas' concept have found that Germans are oriented towards internal control when carrying out any activity (Schroll-Machl, 2003, pp. 45-129). This conclusion is also true of Anglo-Saxons if one takes into account their character traits such as discipline, reasonable thinking (common sense), pragmatism, and individualism (Horodetska, 2003; Kobozeva, 1995). 
Therefore, the fact that Anglo-Saxons and Germans belong to "guilt cultures" is directly or indirectly confirmed by the most common theories of culture types: (1) typology of organizational culture by G. Hofstede, (2) theory of locus of control by J. Rotter and (3) concept of cultural standards by A. Thomas. However, that does not necessarily mean that all European ethnic groups also belong to guilt cultures. For instance, it is unlikely that Ukrainian linguosociety can be defined as a guilt culture since Ukrainians, as has been specified above, have a low indicator of individualism. In addition, the thesis that Ukrainians have an internal locus of control (Reva, 2019, p. 122) needs further studies because, unlike Anglo-Saxons and Germans, Ukrainians go beyond their inner world due a to certain fatality, when they may credit their failures or inaction to some external factors (phantom forces). Moreover, hypersensitivity of a Ukrainian soul and its vulnerability is the reason for the weak strong-willed regulation of Ukrainians, which leads to the fact that emotional sensitivity, contemplativeness, and reverie outweigh the will in their character (Mizin \& Petrov, 2018, p. 121). This feature of the psychological type of the nation has greatly determined cultural standards of Ukrainians: (1) orientation towards hierarchy, (2) indirect management of conflicts and problems, (3) flexibility in communication rules, and (4) high level of uncertainty (indecisiveness, insecurity) (Fink, Gruttauer, \& Thomas, 2008, pp. 12-13).

In view of this, it can be assumed that representatives of Ukrainian linguo-culture tend to be less responsible for their actions than Anglo-Saxons or Germans because they often shift their responsibility to external, sometimes even phantom factors. Such traits of the Ukrainian character as dependency to some extent and irresponsibility originate from the sense of community since collective responsibility involves the opportunity to shift responsibility onto others. The fact that a considerable number of individuals is not ready to take responsibility indicates a certain immaturity of a community as a whole. This is consistent with V. Yushchenko's thesis about Ukrainians as a "quasi-nation". In such a community, shame for misdemeanors transforms into shame in the eyes of people from the community rather than someone's own shame.

One of the ways to verify this assumption is a comparative study of frequent collocates for the following lemmas (Table 1): Ukrainian сором (GRAC), English shame (iWeb, 2021) and German Scham (DWDS, 2021). To ensure the validity of the research findings, it is sufficient to analyze 30 collocates with the highest indices of $\operatorname{logDice}$ or MI-index in each corpus, i.e., not only the frequency of compatibility of these lemmas with other word forms (Freq.), but also an index of the typicality (stability) of this compatibility (if extrapolated to the conceptual level, then Freq. indicates the relevance of a concept in a certain linguo-society, and logDice / MI-index indicate how strongly these concepts correlate to related ones).

With the help of such an analysis, it is possible to identify those cultural concepts, especially emotion ones, which most closely correlate with the concepts of Ukrainian COPOM, AngloSaxon SHAME, and German SCHAM. At the same time, the cross-cultural background enables us to determine more objectively to which culture - guilt or shame - Ukrainians belong. Correlating concepts closest to shame by analogy with the conceptual proximates of U. Oster (2012, p. 338) will be called conceptual proximates. 
Table 1.

Proximates of emotion concepts of Ukrainian COPOM, Anglo-Saxon SHAME and German SCHAM (corpus-based data).

\begin{tabular}{|c|c|c|c|c|c|c|c|c|}
\hline \multicolumn{3}{|c|}{ COPOM } & \multicolumn{3}{|c|}{ SHAME } & \multicolumn{3}{|c|}{ SCHAM } \\
\hline collocates & $\begin{array}{l}\log \\
\text { Dice } \\
\leq 4.0\end{array}$ & $\begin{array}{l}\text { Freq. } \\
\leq 40\end{array}$ & collocates & $\begin{array}{l}\text { MI- } \\
\text { index } \\
\leq 4.0\end{array}$ & $\begin{array}{l}\text { Freq. } \\
\leq 40\end{array}$ & collocates & $\begin{array}{l}\log \\
\text { Dice } \\
\leq 4.0\end{array}$ & $\begin{array}{l}\text { Freq. } \\
\leq 40\end{array}$ \\
\hline $\begin{array}{l}\text { на сором [to } \\
\text { someone's } \\
\text { shame] }\end{array}$ & 9.13 & 276 & guilt & 8.61 & 7424 & $\begin{array}{l}\text { Schande [shame; } \\
\text { ignominy; } \\
\text { dishonor] }\end{array}$ & 10.0 & 118 \\
\hline $\begin{array}{l}\text { ганьба } \\
\text { [ignominy] }\end{array}$ & 8.82 & 393 & self-hatred & 8.04 & 66 & Reue [repentance] & 9.8 & 104 \\
\hline сором [disgrace] & 8.31 & 304 & self-loathing & 8.0 & 126 & Schuld [guilt] & 9.4 & 260 \\
\hline $\begin{array}{l}\text { пекучий } \\
\text { [burning] }\end{array}$ & 7.96 & 168 & embarrassment & 7.86 & 1665 & $\begin{array}{l}\text { Schuldgefühl [sense } \\
\text { of guilt] }\end{array}$ & 9.2 & 57 \\
\hline $\begin{array}{l}\text { стид } \\
\text { [embarrassment] }\end{array}$ & 7.28 & 79 & nakedness & 7.58 & 168 & Trauer [sorrow] & 9.1 & 176 \\
\hline $\begin{array}{l}\text { згоріти } \\
\text { [burn] }\end{array}$ & 7.24 & 112 & unworthiness & 7.56 & 60 & Scheu [cowardice] & 8.9 & 43 \\
\hline $\begin{array}{l}\text { червоніти } \\
\text { [blush] }\end{array}$ & 7.22 & 99 & humiliation & 7.44 & 747 & Stolz [pride] & 8.8 & 95 \\
\hline паленіти [blaze] & 7.18 & 72 & ignominy & 7.41 & 57 & Ekel [disgust] & 8.8 & 49 \\
\hline $\begin{array}{l}\text { почутття } \\
\text { [feeling] }\end{array}$ & 7.15 & 456 & crying & 7.19 & 1183 & Wut [rage] & 8.7 & 142 \\
\hline $\begin{array}{l}\text { набратися } \\
\text { [disgrace oneself] }\end{array}$ & 7.04 & 101 & remorse & 7.12 & 542 & Zorn [anger] & 8.7 & 77 \\
\hline $\begin{array}{l}\text { почервоніти } \\
\text { [flush] }\end{array}$ & 6.91 & 82 & internalized & 7.12 & 45 & Angst [anxiety] & 8.1 & 282 \\
\hline $\begin{array}{l}\text { coвicmb } \\
\text { [consciousness] }\end{array}$ & 6.79 & 119 & disgrace & 7.05 & 532 & Furcht $[$ fear $]$ & 7.9 & 51 \\
\hline $\begin{array}{l}\text { приниження } \\
\text { [humiliation] }\end{array}$ & 6.74 & 75 & dishonour & 7.05 & 120 & Schmerz [pain] & 7.9 & 86 \\
\hline пік [peak] & 6.66 & 63 & stigma & 6.68 & 808 & versinken [sink] & 7.8 & 86 \\
\hline гнів [wrath] & 6.60 & 127 & damn & 6.5 & 1664 & $\begin{array}{l}\text { schweigen [keep } \\
\text { silent] }\end{array}$ & 7.8 & 71 \\
\hline $\begin{array}{l}\text { ганьбити } \\
\text { [embarrass] }\end{array}$ & 6.56 & 50 & reproach & 6.15 & 120 & $\begin{array}{l}\text { Empörung } \\
\text { [indignation] }\end{array}$ & 7.6 & 42 \\
\hline cmpax [fear] & 6.48 & 262 & disgust & 6.0 & 254 & Gefühl [feeling] & 7.5 & 121 \\
\hline $\begin{array}{l}\text { наробити [do } \\
\text { mischief] }\end{array}$ & 6.45 & 67 & ridicule & 5.90 & 110 & erröten [flush] & 6.9 & 44 \\
\hline $\begin{array}{l}\text { провалитися [go } \\
\text { bright red with] }\end{array}$ & 6.41 & 63 & hopelessness & 5.74 & 101 & empfinden [feel] & 6.6 & 89 \\
\hline провина [guilt] & 6.41 & 91 & inadequacy & 5.73 & 114 & $\begin{array}{l}\text { schmerzlich } \\
\text { [painful] }\end{array}$ & 6.2 & 42 \\
\hline $\begin{array}{l}\text { пекти [be } \\
\text { burning] }\end{array}$ & 6.40 & 67 & $\begin{array}{l}\text { self- } \\
\text { consciousness }\end{array}$ & 5.71 & 46 & erfüllen [fill] & 6.1 & 81 \\
\hline $\begin{array}{l}\text { ніяковість } \\
\text { [uneasiness] }\end{array}$ & 6.34 & 43 & overcome & 5.69 & 65 & falsch [faked] & 5.8 & 234 \\
\hline рум'янець [glow] & 6.33 & 47 & damned & 5.57 & 149 & $\begin{array}{l}\text { Peinlichkeit } \\
\text { [annoyance] }\end{array}$ & 5.8 & 40 \\
\hline $\begin{array}{l}\text { oxonumu } \\
\text { [overtake] }\end{array}$ & 6.21 & 81 & secrecy & 5.54 & 277 & $\begin{array}{l}\text { überwinden } \\
\text { [overcome] }\end{array}$ & 5.5 & 41 \\
\hline краска [colour] & 6.20 & 38 & helplessness & 5.45 & 72 & Entsetzen [fright] & 5.4 & 40 \\
\hline відчувати [feel] & 6.19 & 288 & blame & 5.40 & 470 & brennend [burning] & 5.3 & 43 \\
\hline жаль [pity] & 6.16 & 123 & self-doubt & 5.38 & 47 & $\begin{array}{l}\text { Demütigung } \\
\text { [humiliation] }\end{array}$ & 5.3 & 40 \\
\hline $\begin{array}{l}\text { признатися } \\
\text { [confess] }\end{array}$ & 6.12 & 60 & cowardice & 5.09 & 46 & $\begin{array}{l}\text { kollektiv } \\
\text { [collective] }\end{array}$ & 4.8 & 46 \\
\hline $\begin{array}{l}\text { усякий [of every } \\
\text { kind] }\end{array}$ & 6.10 & 93 & regret & 5.06 & 391 & tief [deep] & 4.2 & 65 \\
\hline zpix $[\sin ]$ & 5.99 & 118 & sorrow & 5.04 & 380 & voll [full] & 4.0 & 61 \\
\hline
\end{tabular}


Analysis of the corpus data presented in Table 1 leads to the following conclusions:

1) proximates of the concept COPOM show that the emotion of shame in Ukrainians is manifested mostly collectively, because they associate it primarily with the very shame, disgrace, and humiliation, and the latter, as is commonly known, can occur only within the in-group. At the same time, the concepts of COРОМ and ГАНЬБА reveal the closest connections with this emotion. It is noteworthy that the collective nature of shame caused the relevance of the physiological expression of this emotion in the representatives of the Ukrainian linguosociety (пекучий, згоріти, червоніти, паленіти, etc.). Shame is often accompanied by pangs of conscience and feelings of fear. However, shame associated with sinful acts is no longer so relevant for modern Ukrainians, as stated in some linguistic and cultural studies (e.g., Vdovychenko, 2015). The feeling of guilt for the actions they are ashamed of is also irrelevant for them;

2) as for the concept of SHAME, the AngloSaxons associate it most with guilt, as evidenced by both indices of the lemma guilt. Indicative is the appeal of the proximates of this concept to the individual (self-hatred, self-loathing, selfconsciousness, self-doubt), which is particularly emphasized by the fact that the Anglo-Saxons tend to take the responsibility for those acts (actions) which they are ashamed of. It is because of guilt that AngloSaxon linguistic societies develop selfhatred, self-disgust, and self-loathing. The close connection between shame, guilt, and repentance (redemption) is indicated by a number of synonyms, e.g., remorse, blame, regret;

3) the most relevant proximate of the German concept SCHAM is, as in the case of the Anglo-Saxon SHAME, guilt. Although in terms of intensity of connection, the first positions are occupied by shame (dishonor, disgrace) and remorse. It is noteworthy that the relevance of guilt is reinforced by the lemma Schuldgefühl (feeling of guilt), which occupies the fourth position, i.e. shame for Germans is a destructive (painful) emotion that makes them feel guilty for their actions and repent, which causes anger and disgust to themselves. Unlike Ukrainians and Anglo-Saxons, the Germans associate the concept SCHAM with fear, e.g., Angst, Furcht, Entsetzen.
The foregoing gives grounds for asserting that Ukrainians, although a European linguo-society, belong not to guilt culture, as the Anglo-Saxons and Germans, but to shame culture, because this emotion arises in them mostly in in-groups, transforming into shame, humiliation, pangs of conscience, but not guilt. This feature of Ukrainians' psychological type brings them closer to Eastern cultures, correlating to the greatest extent with such a criterion of cultures distinctions as collectivism-individualism. The high rate of collectivism in modern Ukrainian linguistic society can be explained by geographical (Ukraine is the geographical midpoint between the West and the East) as well as historical and political (until recently Ukrainians were in the bosom of the empire, where dictatorial collectivism dominated). Among other factors, one should mention that Ukrainians had never had their own state. Obviously, this has led to a very high index of power distance in Ukrainian society - 92 positions out of 100 (Hofstede Insights, 2019), which indicates, in particular, the political immaturity of Ukrainians. All these together gave rise to clannishness among Ukrainians, where each of them puts the interests of their "clan" above the interests of "others". In such a society, violation of norms and rules leads to the feeling of shame, as there is always an opportunity to shift one's responsibility (blame) onto "others". Such emotional immaturity is closely related to cultural immaturity, i.e., social infantilism. Taking this into account, the opinion that the emotion concept of COPOM is one of the markers of infantilism in Ukrainian linguoculture can be considered quite reasonable.

\section{Conclusions}

The proposed cross-cultural study has found that the emotion concept of SHAME has a specific ethno-cultural nature in the Ukrainian, AngloSaxon, and German linguistic cultures, which directly correlates with the national characteristics of the representatives of these linguo-cultures. A comparative analysis of data from representative Ukrainian, English, and German corpora has revealed that this concept may be one of the markers of the infantilism of the Ukrainian people and confirmed the assumption that the clearly expressed infantilism of Ukrainians is associated with changes in their psychological type, especially with a low rate of individualism. Because of collectivism, representatives of the Ukrainian linguo-culture tend to be less responsible for their actions than Anglo-Saxons or Germans, often shifting their responsibility to external, sometimes even 


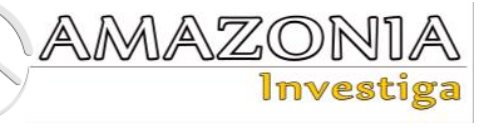

phantom factors. The unwillingness of a large number of individuals to take responsibility indicates a certain immaturity of the society as a whole. In such a society, the shame for their misdeeds is transformed, as a rule, not into their own guilt, but shame in front of "others".

\section{Bibliographic references}

Benedict, R. (1989). The Chrysanthemum and the Sword: Patterns of Japanese Culture. Boston, Mass.: Houghton Mifflin.

Breslav, G.M. (2004). The Psychology of Emotions. Moscow: Smysl \& Academy. Retrieved from https://gigabaza.ru/doc/92858.html

Cowen, A.S. \& Keltner, D. (2017). Self-report captures 27 distinct categories of emotion bridged by continuous gradients. Proceedings of the national academy of sciences, 114(38), 7900-7909. https://doi.org/10.1073/pnas.1702247114

Du, S., Tao, Y., \& Martinez, A.M. (2014). Compound facial expressions of emotion. Proceedings of the national academy of sciences, 111(15), 1454-1462. https://doi.org/10.1073/pnas.1322355111

DWDS. (2021). Digital dictionary of the German language. Retrieved from http://www.dwds.de/ressourcen/korpora/

Farber, M.L. (1950). The Problem of National Character: A Methodological Analysis. The Journal of Psychology, 30(2), 307-316. https://doi.org/10.1080/00223980.1950.991606 8

Fink, L., Gruttauer, S., \& Thomas, A. (2008). Professionally in Ukraine. Training program for managers, specialists and executives. Goettingen: Vandenhoeck \& Ruprecht.

Friedlmeier, W., Corapci, F., \& Cole, P.M. (2011). Socialization of Emotions in Cross-cultural Perspective. Social and Personality Psychology Compass, 5(7), 410-427. https://doi.org/10.1111/j.17519004.2011.00362.x

GRAC. (2021). The General Regionally Annotated Corpus of Ukrainian. Retrieved from http://www.uacorpus.org/Kyiv/ua/

Hofstede, G.J. (2006). Think locally, act globally. Intercultural cooperation and global management. Munich: Beck.

Hofstede Insights. (2019). Country Comparison. Retrieved from https://www.hofstedeinsights.com/product/compare-countries/

Hopko, H. (2019). Maturity test" of Society. Newspaper of the day. Retrieved from https://m.day.kyiv.ua/uk/article/denplanety/test-na-zrilist-suspilstva

Horodetska, O.V. (2003). National-marked Concepts in the British Linguistic Picture of the World of the XX Century (Thesis' Abstract). Taras Shevchenko National University of Kyiv.
Kyiv. Retrieved from http://www.irbisnbuv.gov.ua/cgi-

bin/irbis_nbuv/cgiirbis_64.exe?Z21ID=\&I21D $\mathrm{BN}=\mathrm{ARD} \& \mathrm{P} 21 \mathrm{DBN}=\mathrm{ARD} \& \mathrm{~S} 21 \mathrm{STN}=1 \& \mathrm{~S} 21$ $\mathrm{REF}=10 \& \mathrm{~S} 21 \mathrm{FMT}=$ fullwebr $\& \mathrm{C} 21 \mathrm{COM}=\mathrm{S} \& \mathrm{~S}$ $21 \mathrm{CNR}=20 \& S 21 \mathrm{P} 01=0 \& S 21 \mathrm{P} 02=0 \& S 21 \mathrm{P} 03=$ $\mathrm{A}=\& \mathrm{~S} 21 \mathrm{COLORTERMS}=1 \& \mathrm{~S} 21 \mathrm{STR}=\% \mathrm{D} 0$ $\% 93 \% \mathrm{D} 0 \% \mathrm{BE} \% \mathrm{D} 1 \% 80 \% \mathrm{D} 0 \% \mathrm{BE} \% \mathrm{D} 0 \% \mathrm{~B} 4 \%$ D0\%B5\%D1\%86\%D1\%8C\%D0\%BA\%D0\%B 0\%20\%D0\%9E.\%D0\%92.\$

Hundorova, T. (2019). Literature of Our Independence. National Academy of Sciences of Ukraine. Retrieved from https://www.nas.gov.ua/UA/Messages/Pages/V iew.aspx?MessageID=5644

Inkeles, A. (1997). National Character: A Psychosocial Perspective. New Brunswick, NJ: Transaction Publishers.

iWeb. (2021). Word Web Corpus. Retrieved from https://www.english-corpora.org/iweb/

Izard, C.E. (1992). Basic Emotions, Relations among Emotions, and Emotion-cognition Relations. Psychological Review, 99(3), 561565 295X.99.3.561

Kitayama, S. \& Markus, H.R. (1997). Emotion and Culture: Empirical Studies of Mutual Influence. Washington, DC: American Psychological Association.

Kobozeva, I.M. (1995). German, English, French, and Russian: Revealing Stereotypes of National Character through Analysis of Ethnonym Connotations. Moscow University Philology Bulletin, 3, 102-117. Retrieved from http://otipl.philol.msu.ru/staff/people/kobozeva .php

Kostomarov, N.I. (1991). Two Russian Nationalities. Kiev \& Kharkov: Maydan. Retrieved from https://dlib.kiev.ua/items/show/576\#?c=0\&m= $0 \& \mathrm{~s}=0 \& \mathrm{cv}=0$

Kövecses, Z. (1986). Metaphors of Anger, Pride, and Love: A Lexical Approach to the Structure of Concepts. Amsterdam: John Benjamins.

Kövecses, Z. (1990). Emotion Concepts. New York: Springer.

Kozlovskyi, I. (2021). We are Bound by the Rope of Our Faith. The Ukrainians. Retrieved from https://theukrainians.org/ihor-kozlovskyi-naszviazuie-motuzka-viry/

Kulchytskyi, O. (1949). Features of Characterology of the Ukrainian People. U V. Kubiiovych \& Z. Kudelia (Red.), Encyclopedia of Ukrainian culture, T. 1 (s. 708-718). Munich \& New York: Young life.

Levenson, R.W. (2011). Basic emotion questions. Emotion Review, 3(4), 379-386. https://doi.org/10.1177/1754073911410743

Lewandowska-Tomaszczyk, B. (2017). Identity, emotions and cultural differences in English and Polish online comments. International Journal 
of Language and Culture, 4(1), 47-71. https://doi.org/10.1075/ijolc.4.1.04lew

McCrae, R.R. \& Terracciano, A. (2006). National Character and Personality. Current Directions in Psychological Science, 15(4), 156-161. https://doi.org/10.1111/j.14678721.2006.00427.x

Mizin, K.I. \& Petrov, O.O. (2018). Contrastive Linguoculturology: Methodological Problems and Perspective Methods. PereiaslavKhmelnytskyi; Vinnytsia; Kremenchuk: Shcherbatykh. Retrieved from https://dspace.vspu.edu.ua/bitstream/handle/12 3456789/9351/\%D0\%9C\%D1\%96\%D0\%B7 $\% \mathrm{D} 1 \% 96 \% \mathrm{D} 0 \% \mathrm{BD} \% \mathrm{D} 0 \% 9 \mathrm{~F} \% \mathrm{D} 0 \% \mathrm{~B} 5 \% \mathrm{D} 1$ $\% 82 \% \mathrm{D} 1 \% 80 \% \mathrm{D} 0 \% \mathrm{BE} \% \mathrm{D} 0 \% \mathrm{~B} 2 \_\% \mathrm{D} 0 \% 97$ $\% \mathrm{D} 1 \% 96 \% \mathrm{D} 1 \% 81 \% \mathrm{D} 1 \% 82 \% \mathrm{D} 0 \% \mathrm{~B} 0 \% \mathrm{D} 0 \%$ B2\%D0\%BD\%D0\%B0\%20\%D0\%9B\%D0\%9 A.pdf?sequence $=1 \&$ isAllowed $=y$

Mizin, K. \& Korostenski, J. (2020). In Addition to the Discussion on the "Methodological Primitivism" in Linguoculturology. Linguistic Studies, 39, 107-117. https://doi.org/10.31558/1815-3070.2020.39.9

Mizin, K. \& Petrov, O. (2021). Emotional State GEMÜTLICHKEIT in Cross- cultural Perspective: Corpus-based Approach. Studies about Languages / Language studies, 38, 43-60. http://doi.org/10.5755/j01.sal.1.38.26581

Mizin, K., Slavova, L. \& Khmara, V. (2021). The equivalence of terms denoting the emotion concepts of Ger. angst and A.-S. fear: A corpusbased method. Lege artis, 6(2),

$69-$ $104 . \quad$ https://lartis.sk/wpcontent/uploads/2021/12/Mizin_et_al.pdf

Oster, U. (2012). "Angst" and "Fear" in Contrast: A Corpus-based Analysis of Emotion Concepts. In M. Brdar, I. Raffaelli, M. Žic Fuchs (Eds.), Cognitive Linguistics between Universality and Variation (pp. 327-355). Newcastle upon Tyne: Cambridge Scholars Publishing.

Reva, I. (2019). On the Other Side: The Sociopsychological and Cultural Consequences of the Holodomor and Stalin's Repressions. Kyiv: K.I.S. (In Ukranian)

Rotenberg, V.S. (2009). An Infantilism of the Intellectually and Spiritually Matured Personality: Soaring and Precipice. Activitas Nervosa Superior, 51(3), 162-166.

Rotter, J.B. (1954). Social Learning and Clinical Psychology. New York: Prentice-Hall, Inc.

Schroll-Machl, S. (2003). The Germans - We Germans. Perception of others and self-view in professional life. Göttingen: Vandenhoeck \& Ruprecht.

Schwarz-Friesel, M. (2008). Language, Cognition, and Emotion: New Paths in Cognitive Science. In H. Kämper \& L.M. Eichinger (Ed.), Language - Cognition - Culture. Language between mental structure and cultural imprint (S. 277-301). Berlin \& New York: de Gruyter.

Stefanowitsch, A. (2020). Corpus Linguistics: A Guide to the Methodology. Berlin: Language Science Press. https://doi.org/10.5281/zenodo.3735822

Strazhnyi, O. (2017). Ukrainian Mentality: Illusions - Myths - Reality. Kyiv: Spirit and letter, http://resource.history.org.ua/item/0014216

Thomas, A. (2018). Orientation in Cultural and Ethnic Diversity. The Concept of Cultural Standards. In A. Thomas (Ed.), Cultural and Ethnic Diversity. How European Psychologists Can Meet the Challenges (pp. 25-37). Göttingen: Hogrefe. Retrieved from https://books.google.com.ua/books?id=5wFQD wAAQBAJ\&printsec $=$ frontcover\&hl=ru\&sour

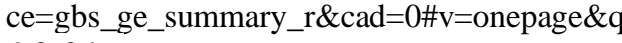
$\& \mathrm{f}=$ false

Tracy, J.L. \& Matsumoto, D. (2008). The Spontaneous Display of Pride and Shame: Evidence for Biologically Innate Nonverbal Displays. Proceedings of the National Academy of Sciences of the United States of America, 105 , 11655-11660. https://doi.org/10.1073/pnas.0802686105

Vdovychenko, N.V. (2015). Verbalization of Moral and Ethical Concepts in the Linguistic Picture of the World (Dissertation for a degree Candidate of Philological Sciences). Odessa I.I. Mechnikov National University. Odesa. Retrieved from https://pdfs.semanticscholar.org/9fb5/737956b 9baeee0bc092fc7902450007695a3.pdf

Wierzbicka, A. (1999). Emotions Across Languages and Cultures: Diversity and Universals. Cambridge: Cambridge University Press.

Yaniv, V. (2006). Essays on the History of Ukrainian Ethnopsychology. Kyiv: Znannia. http://irbisnbuv.gov.ua/ulib/item/ukr0000015046

Yushchenko, V. (2021). Exclusive Interview with N. Vlashchenko. Youtube. Retrieved from https://www.youtube.com/watch?v=FS8anF6K $15 \mathrm{U}$ 